\title{
IMPORTÂNCIA DO DIAGNÓSTICO DIFERENCIAL DE ESTRIDOR NA PEDIATRIA- RELATO DE CASO
}

\author{
Rafaela Lima Nogueira \\ Hospital Regional João Penido / FHEMIG \\ rafela_nogueira@yahoo.com.br \\ Camila Magalhães Silva \\ Hospital das Clínicas de Belo Horizonte \\ camila.magalhaes@live.com \\ Sílvia Paschoalini Azalim de Castro \\ Hospital Regional João Penido - HRJP/FHEMIG \\ silviaazalim@gmail.com
}

\section{RESUMO}

INTRODUÇÃO: estridor é um sintoma comum dentro da pediatria com várias possibilidades diagnósticas, e para isso, o pediatra deve estar atento para identificá-las. DESCRIÇÃO DO CASO: lactente de 4 meses, masculino, peso 3.695g, atendido no ambulatório de Pneumologia Pediátrica, com estridor, referido desde o nascimento, esforço respiratório moderado, tiragem intercostal com diagnóstico de laringomalácea. Ao exame físico: hipocorado $+/ 4+$, hidratado, acianótico, anictérico, afebril, Sat O2 94\% cateter nasal IL/min, freqüência respiratória 60 Irpm, com esforço moderado, estridor, roncos de transmissão e tiragem intercostal. Aparelho cardiovascular, abdominal, genital sem alterações. Apresentava peso abaixo do escore Z-3. Foi necessário avançar na propedêutica pois a criança mantinha o estridor, esforço respiratório e dificuldade de ganho de peso. Sem histórias patológicas pregressa significativa. Nos exames de imagem a tomografia de tórax evidenciou estrias atelectásicas esparsas nos lobos superiores e lobo inferior de pulmão esquerdo. Ausência de adenomegalia mediastinal. Coração e vasos da base de aspecto anatômico. Realizou-se a broncoscopia onde se observou paralisia de pregas vocais bilateral através da fenda glótica, com indicação de traqueostomia. Traquéia e brônquios endoscopicamente normais. Procedimento de traqueostomia foi realizado com melhora significativa do padrão respiratório da criança, com entrada de ar bilateral simétrica, sem esforço, sat $98 \%$ em ar ambiente e recuperação nutricional. DISCUSSÃO: Várias causas de estridor em lactentes são descritas na literatura levando o médico assistente a pensar nestas possibilidades e, partir para ampliar a propedêutica, caso a anamnese e exame físico não sejam suficientes para se fechar o diagnóstico. São descritas como causas de estridor em lactentes a laringomalácea, paralisia de pregas vocais, estenoses de laringe, membranas laríngeas, anel vascular, estenose subglótica entre outras. CONCLUSÃO: Assim, diante de lactentes com estridor e evolução atípica deve-se indicar a broncoscopia que possui papel fundamental no esclarecimento diagnóstico diante das várias possibilidades de diagnósticos diferenciais.

PALAVRAS-CHAVES: Estridor, Broncoscopia, Paralisia de cordas vocais. 